\title{
Analisis Tahapan Konstruksi Jembatan Cable Stayed dengan Metode Kesetimbangan Kantilever
}

\author{
ANISSA, BERNARDINUS HERBUDIMAN, EUNEKE WIDYANINGSIH
}

Program Studi Teknik Sipil, Institut Teknologi Nasional Bandung

Email: anissarania02@gmail.com

\begin{abstract}
ABSTRAK
Jembatan cable stayed merupakan struktur jembatan yang memiliki sederetan kabel yang menghubungkan pilon dan girder. Dalam pembangunan jembatan cable stayed perlu dilakukan analisis pada tahap konstruksi. Penelitian ini menganalisis tahapan konstruksi jembatan cable stayed menggunakan metode kesetimbangan kantilever untuk menghasilkan besarnya gaya-gaya dalam yang memenuhi syarat. Berdasarkan hasil penelitian, tegangan kabel maksimum yaitu 404,6 MPa dengan tegangan putus yaitu $837 \mathrm{MPa}$. Nilai lendutan terendah terdapat pada segmen 1 yaitu 0,001 $\mathrm{m}$. Nilai lendutan tertinggi terdapat pada segmen 20 yaitu 0,167 m. Kemudian mengalami penurunan pada tahap 21 sebesar 0,153 m. Lendutan yang terjadi memiliki nilai di bawah lendutan izin yaitu 0,375 m. Momen terbesar terjadi pada segmen 21 yaitu 18.286,31 kNm; sedangkan yang terendah pada segmen 11 yaitu 20,43 kNm. Momen maksimum yang terjadi akibat layan yaitu $68.003 \mathrm{kNm}$ dengan batas kapasitas izin yaitu 190.500,13 kNm. Berdasarkan hasil yang diperoleh, dapat disimpulkan bahwa struktur jembatan aman pada tahap pelaksanaan dan juga pasca konstruksi.
\end{abstract}

Kata kunci: cable stayed, tegangan kabel, lendutan, gaya dalam

\begin{abstract}
The cable-stayed bridge is structure of a bridge that have an align of cables which connecting to a pilon and a girder. Through a cable-stayed bridge constructor, it is necessary to construge stage. This research analyzing a phase of constructor a cable-stayed bridge using equilibrium cantiveler method's to produce a within forces which is fullfill requirement. According to the result of the research, the highest tension of the cable is $404.6 \mathrm{MPa}$ and ultimate tension is $837 \mathrm{MPa}$. The lowest deflection value occur at the segment 1 is $0.001 \mathrm{~m}$. The highest deflection value occur at the segment 20 is $0.0167 \mathrm{~m}$. Subsequently undergo decreasing on the phase 21 is $0.153 \mathrm{~m}$. The deflection that occur has value below the deflection permit is $0.375 \mathrm{~m}$. The highest moment occur at the segment 21 is $18,286.31 \mathrm{kNm}$; on the other hand the lowest moment occur at the segment 11 is $20.43 \mathrm{kNm}$. The maximum moment that occurs due to the service is $68,003 \mathrm{kNm}$ with a permit capacity limit og 190,500.13 kNm. According to the result of the research, so that in conclude, the structure is safe on the execution phase and also the postconstruction phase.
\end{abstract}

Keywords: cable stayed, tension cable, displacement, beam force 


\section{PENDAHULUAN}

Jembatan merupakan struktur konstruksi yang berfungsi sebagai penghubung antar wilayah yang terdapat rintangan-rintang seperti sungai, rawa-rawa, laut, dan sebagainya. Dalam pembangunan jembatan perlu dilakukan analisis terlebih dahulu baik pada saat tahap konstruksi maupun kondisi layan. Tahap konstruksi jembatan memiliki berbagai macam metode, salah satunya metode kesetimbangan kantilever. Metode ini umumnya digunakan untuk pembangunan jembatan bentang panjang secara bertahap. Jembatan cable stayed merupakan salah satu jembatan bentang panjang. Penelitian ini menganalisis tahapan konstruksi jembatan cable stayed menggunakan metode kesetimbangan kantilever untuk menghasilkan besarnya gaya-gaya dalam yang memenuhi aspek masa pelaksanaan.

\section{TINJAUAN PUSTAKA}

\subsection{Jembatan Cable Stayed}

Jembatan cable stayed merupakan struktur jembatan yang memiliki sederetan kabel yang menjadi tumpuan yang dihubungkan dengan pilon sebagai penahan utama untuk menyalurkan beban yang bekerja pada lantai dek jembatan menuju pondasi.

\subsection{Komponen Utama Jembatan Cable Stayed}

Komponen utama jembatan cable stayedterdiri atas pilon, gelagar dan kabel. Masing-masing komponen mempunyai berbagai tipe dan bentuk sesuai fungsinya.

1. Pilon merupakan elemen yang berfungsi untuk menahan tekanan tinggi karena memikul hampir semua berat sendiri dan beban hidup yang berada pada struktur. Menara akan menerima gaya dari gelagar yang disalurkan melalui kabel menuju pondasi.

2. Gelagar merupakan elemen yang menerima beban-beban yang bekerja pada jembatan kemudian disalurkan menuju sederetan kabel penggantung (stays).

3. Kabel merupakan elemen yang menghubungkan antara pilon dan gelagar untuk menyalurkan beban-beban yang terjadi pada gelagar menuju pilon yang diteruskan ke pondasi. Kabel terdiri dari dua bagian yaitu kabel backstay dan kabel midstay.

\subsection{Pembebanan Struktur Jembatan}

Dalam penelitian ini pembebanan terbagi menjadi 2 yaitu tahap konstruksi dan pasca konstruksi. Dalam penelitian ini pembebanan jembatan cable stayed menggunakan peraturan SNI 1725:2016. Pembebanan struktur jembatan disajikan pada Tabel 1 dan Tabel 2 berikut.

Tabel 1. Pembebanan Jembatan Cable Stayed Tahap Konstruksi

\begin{tabular}{cc}
\hline Beban & Items \\
\hline Beban permanen & Berat sendiri \\
\hline Beban alat konstruksi & Traveling crane \\
\hline Beban dinamis & Beban gempa \\
\hline
\end{tabular}

Tabel 2. Pembebanan Jembatan Cable Stayed Pasca Konstruksi

\begin{tabular}{cc}
\hline Beban & \multicolumn{1}{c}{ Items } \\
\hline \multirow{2}{*}{ Beban permanen } & Berat sendiri \\
\cline { 2 - 2 } & Beban mati tambahan \\
\hline \multirow{3}{*}{ Beban hidup } & Beban lajur (TD) \\
\cline { 2 - 2 } & Beban truk (TT) \\
\cline { 2 - 2 } & Beban rem (TB) \\
\hline
\end{tabular}


Tabel 2. Pembebanan Jembatan Cable Stayed Pasca Konstruksi lanjutan

\begin{tabular}{lc}
\hline \multicolumn{1}{c}{ Beban } & \multicolumn{1}{c}{ Items } \\
\hline \multirow{2}{*}{ Beban akibat aksi lingkungan } & Beban angin pada struktur \\
\cline { 2 - 2 } & Beban angin pada kendaraan \\
\hline Beban dinamis & Beban gempa \\
\hline
\end{tabular}

(Sumber: Badan Standardisasi Nasional, 2016)

\subsection{Kombinasi Pembebanan}

Kombinasi pembebanan berfungsi untuk menghasilkan kondisi esktrem akibat beban yang bekerja. Kombinasi pembebanan terbagi menjadi 2 yaitu tahap dan pasca konstruksi. Kombinasi pembebanan struktur jembatan disajikan pada Tabel $\mathbf{3}$ dan Tabel $\mathbf{4}$ berikut.

Tabel 3. Kombinasi Pembebanan Jembatan Cable Stayed Tahap Konstruksi

\begin{tabular}{lcc}
\multicolumn{1}{c}{ Beban } & Items & Kombinasi Pembebanan \\
\hline Beban permanen & Berat sendiri & 1 \\
\hline Beban alat konstruksi & Traveling crane & 1 \\
\hline Beban dinamis & Beban gempa & 1 \\
\hline
\end{tabular}

Tabel 2. Kombinasi Pembebanan Jembatan Cable Stayed Pasca Konstruksi

\begin{tabular}{|c|c|c|c|c|c|c|c|c|c|c|c|c|}
\hline \multirow[b]{2}{*}{$\begin{array}{c}\text { Keadaan } \\
\text { Batas }\end{array}$} & \multirow{2}{*}{$\begin{array}{l}\text { MS } \\
\text { MA } \\
\text { TA } \\
\text { PR } \\
\text { PL } \\
\text { SH }\end{array}$} & \multirow{2}{*}{$\begin{array}{l}\text { TD } \\
\text { TT } \\
\text { TB } \\
\text { TR } \\
\text { TP }\end{array}$} & \multirow[b]{2}{*}{ EU } & \multirow[b]{2}{*}{$\mathbf{E W}_{\mathbf{s}}$} & \multirow[b]{2}{*}{$E W_{\mathbf{I}}$} & \multirow[b]{2}{*}{ BF } & \multirow[b]{2}{*}{ Eun } & \multirow[b]{2}{*}{ TG } & \multirow[b]{2}{*}{ ES } & \multicolumn{3}{|c|}{$\begin{array}{l}\text { Gunakan } \\
\text { Salah Satu }\end{array}$} \\
\hline & & & & & & & & & & EQ & TC & TV \\
\hline Kuat I & $\gamma_{p}$ & 1,80 & 1,00 & - & - & 1,00 & $0,50 / 1,20$ & $\gamma_{\mathrm{TG}}$ & $\gamma_{\mathrm{ES}}$ & - & - & - \\
\hline Kuat II & $\gamma_{p}$ & 1,40 & 1,00 & - & - & 1,00 & $0,50 / 1,20$ & $\gamma_{\mathrm{TG}}$ & $\gamma_{\mathrm{ES}}$ & - & - & - \\
\hline Kuat III & $\gamma_{p}$ & - & 1,00 & 1,40 & - & 1,00 & $0,50 / 1,20$ & $\gamma_{\mathrm{TG}}$ & $\gamma_{\mathrm{ES}}$ & - & - & - \\
\hline Kuat IV & $\gamma_{p}$ & - & 1,00 & - & - & 1,00 & $0,50 / 1,20$ & - & - & - & - & - \\
\hline Kuat V & $\gamma_{p}$ & - & 1,00 & 0,40 & 1,00 & 1,00 & $0,50 / 1,20$ & $\gamma_{\mathrm{TG}}$ & $\gamma_{\mathrm{ES}}$ & - & - & - \\
\hline Ekstrem I & $\gamma_{p}$ & $\gamma_{\mathrm{EQ}}$ & 1,00 & - & - & 1,00 & - & - & - & 1,00 & - & - \\
\hline Ekstrem II & $\gamma_{p}$ & 0,5 & 1,00 & - & - & 1,00 & - & - & - & - & 1,00 & 1,00 \\
\hline Daya Layan I & 1,00 & 1,00 & 1,00 & 0,30 & 1,00 & 1,00 & $1,00 / 1,20$ & $\gamma_{\mathrm{TG}}$ & $\gamma_{\mathrm{ES}}$ & - & - & - \\
\hline Daya Layan II & 1,00 & 1,30 & 1,00 & - & - & 1,00 & $1,00 / 1,20$ & - & - & - & - & - \\
\hline Daya Layan III & 1,00 & 0,80 & 1,00 & - & - & 1,00 & $1,00 / 1,20$ & $\gamma_{\mathrm{TG}}$ & $\gamma_{\mathrm{ES}}$ & - & - & - \\
\hline Daya Layan IV & 1,00 & - & 1,00 & 0,70 & - & 1,00 & $1,00 / 1,20$ & - & 1,00 & - & - & - \\
\hline Fatik (TD dan TR) & - & 0,75 & - & - & - & - & - & - & - & - & - & - \\
\hline
\end{tabular}

(Sumber: Badan Standardisasi Nasional, 2016)

\subsection{Metode Konstruksi Jembatan Cable Stayed Secara Bertahap}

Dalam penelitian ini menggunakan metode kesetimbangan kantilever. Metode kesetimbangan kantilever merupakan metode pelaksanaan konstruksi jembatan dengan memanfaatkan efek kantilever seimbangnya sehingga struktur dapat berdiri sendiri. Metode kesetimbangan kantilever terdapat bebarapa jenis metode konstruksi sebagai berikut:

1. Metode kesetimbangan kantilever dengan launching gantry

Metode ini digunakan alat konstruksi gantry sebagai peluncur segmen-segmen gelagar hasil precast.

2. Metode kesetimbangan kantilever dengan lifting frame

Metode ini digunakan alat konstruksi travelling crane sebagai peluncur segmen-segmen gelagar hasil precast.

3. Metode kesetimbangan kantilever dengan crane 
Metode ini digunakan alat konstruksi crane untuk mengangkat segmen-segmen gelagar atau pilon.

4. Metode kesetimbangan kantilever dengan full span

Metode ini hanya dapat dipakai untuk jembatan bentang pendek.

5. Metode kesetimbangan kantilever dengan from traveller method

Metode ini digunakan alat konstruksi form traveller untuk mengangkat segmen-segmen gelagar.

\subsection{Tahapan Konstruksi Jembatan Cable Stayed}

Dalam penelitian ini perencanaan pilon dianggap sudah cukup kaku, maka tahapan dimulai saat segmen gelagar pertama dinaikan. Kemudian dilanjutkan dengan segmen gelagar berikutnya. Penjepitan sementara di pilon dapat dibongkar setelah pemasangan dan penarikan kabel selesai. Dengan membuat kantilever ke dalam bentang utama dan bentang luar kabel dipasang pada pilon dan gelagar sehingga susunan kipas atau harpa dari bentang samping ditentukan secara bersamaan dengan yang berasal dari bentang utama. Sketsa tahapan pelaksanaan digunakan bantuan program SketchUp diuraikan sebagai berikut:

1. Tahap Pertama

Didirikan bangunan bawah yaitu pondasi dan pilon kemudian menara terlihat pada Gambar 1.

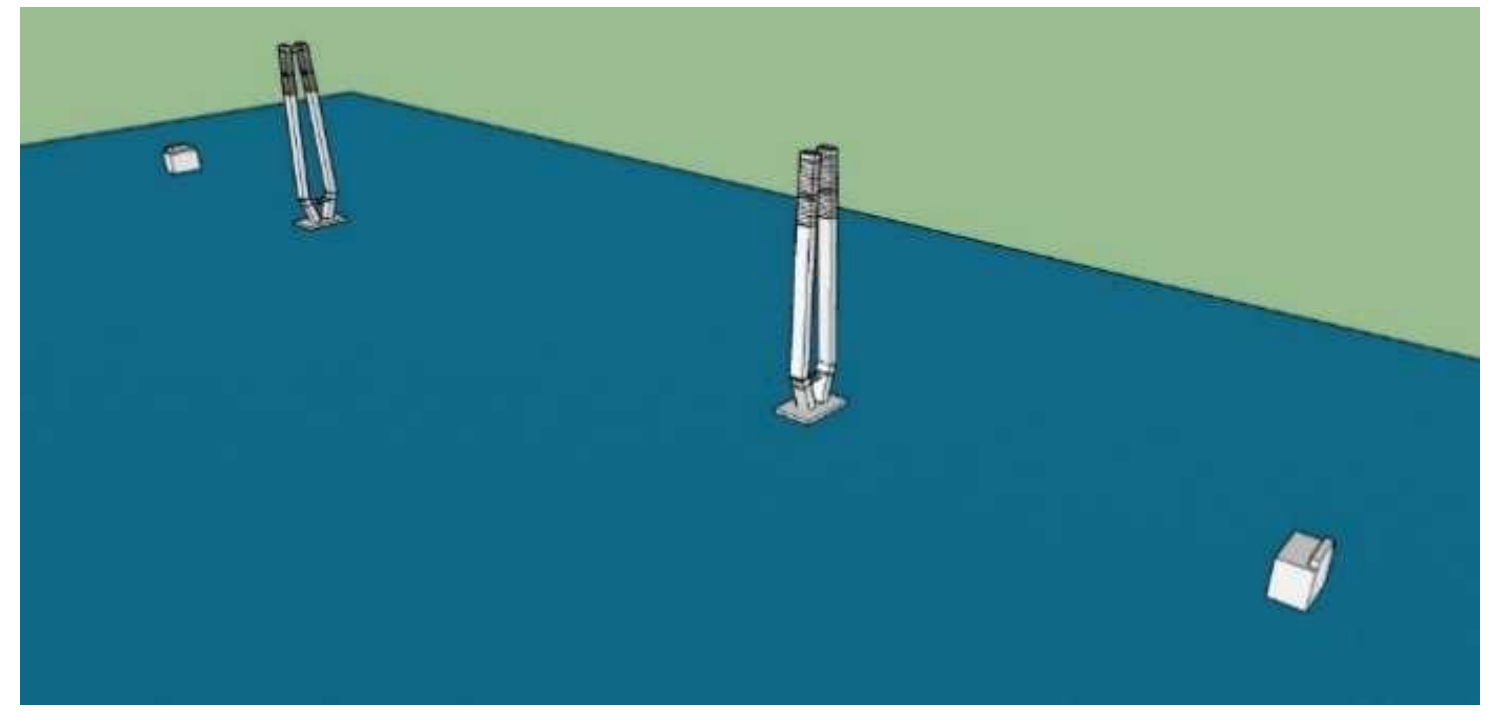

Gambar 1. Sketsa bangunan pilon dan abutmen jembatan

2. Tahap Kedua

Pemasangan segmen dek pertama menggunakan floating crane, sebagaimana terlihat pada Gambar 2. 


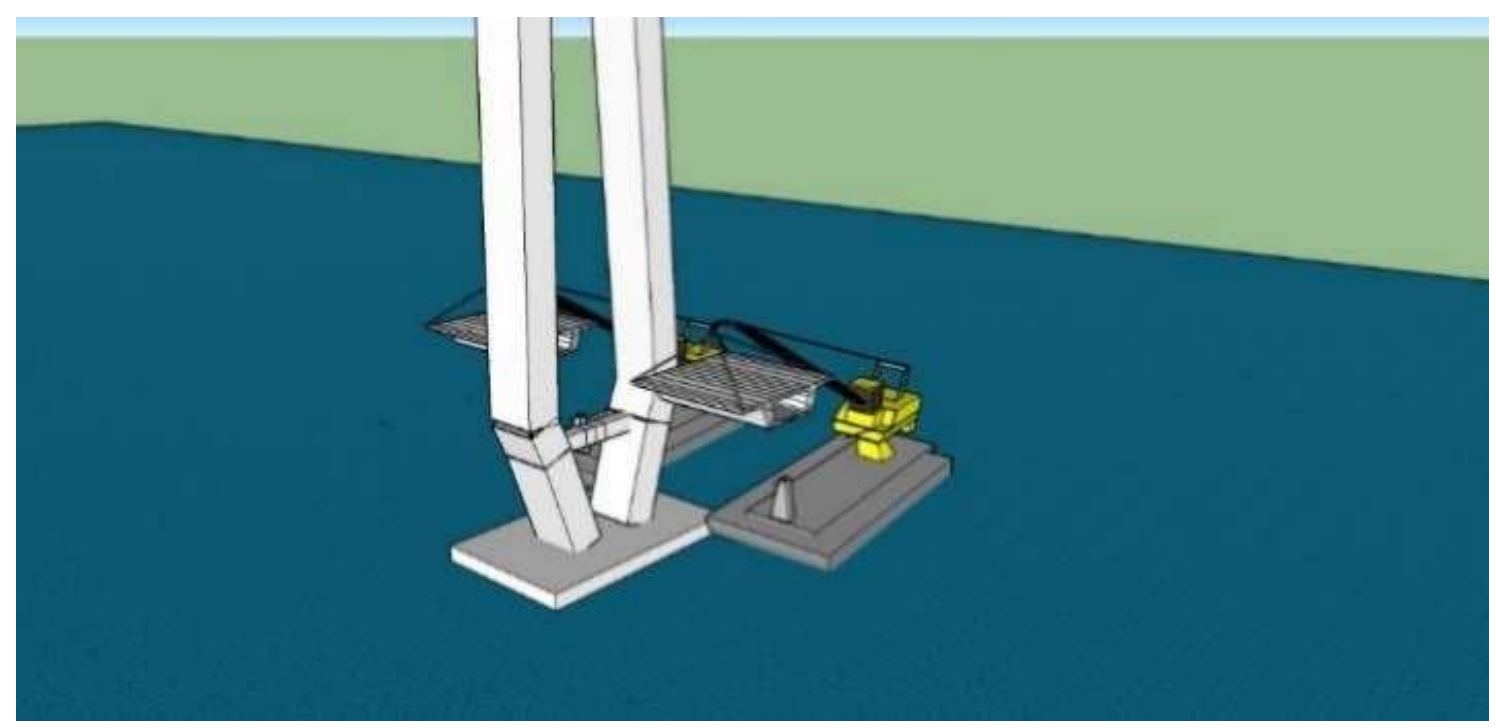

Gambar 2. Sketsa pemasangan gelagar 1

3. Tahap Ketiga

Pemasangan segmen dek selanjutnya menggunakan traveling crane. Kemudian pemasangan kabel dan dilakukan jacking pada pilon, sebagaimana terlihat pada Gambar 3.

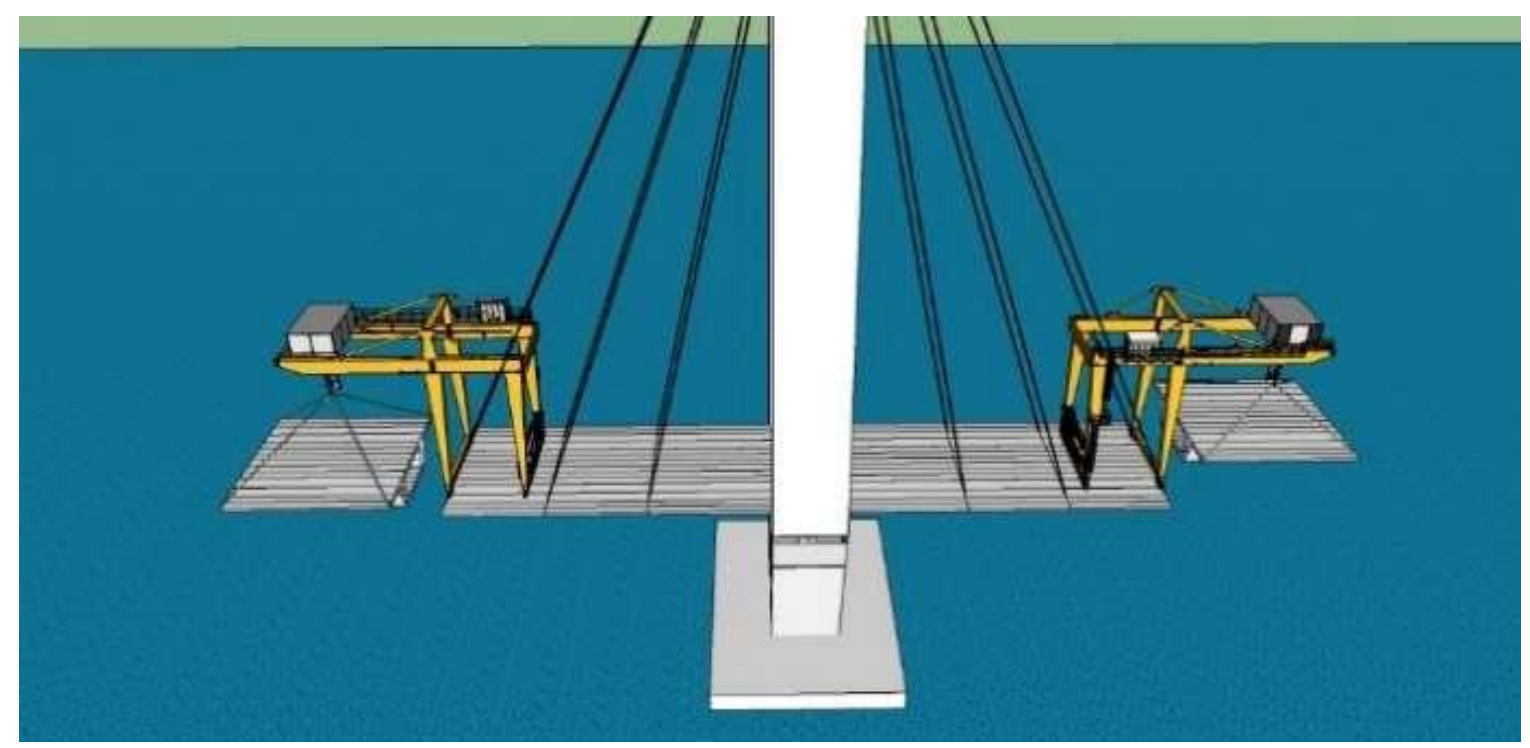

Gambar 3. Sketsa pemasangan dek menggunakan traveling crane

4. Tahap Keempat

Pada tahap ini, segmen-segmen dek lainnya terus dipasang sesuai dengan metode pada tahap ketiga sampai segmen dek mencapai jarak yang sudah direncanakan. Kemudian pada segmen dengan jarak yang sudah dekat dengan abutment pemasangan segmen dek dilakukan masih menggunakan travelling crane. Sketsa dapat dilihat pada Gambar 4. 


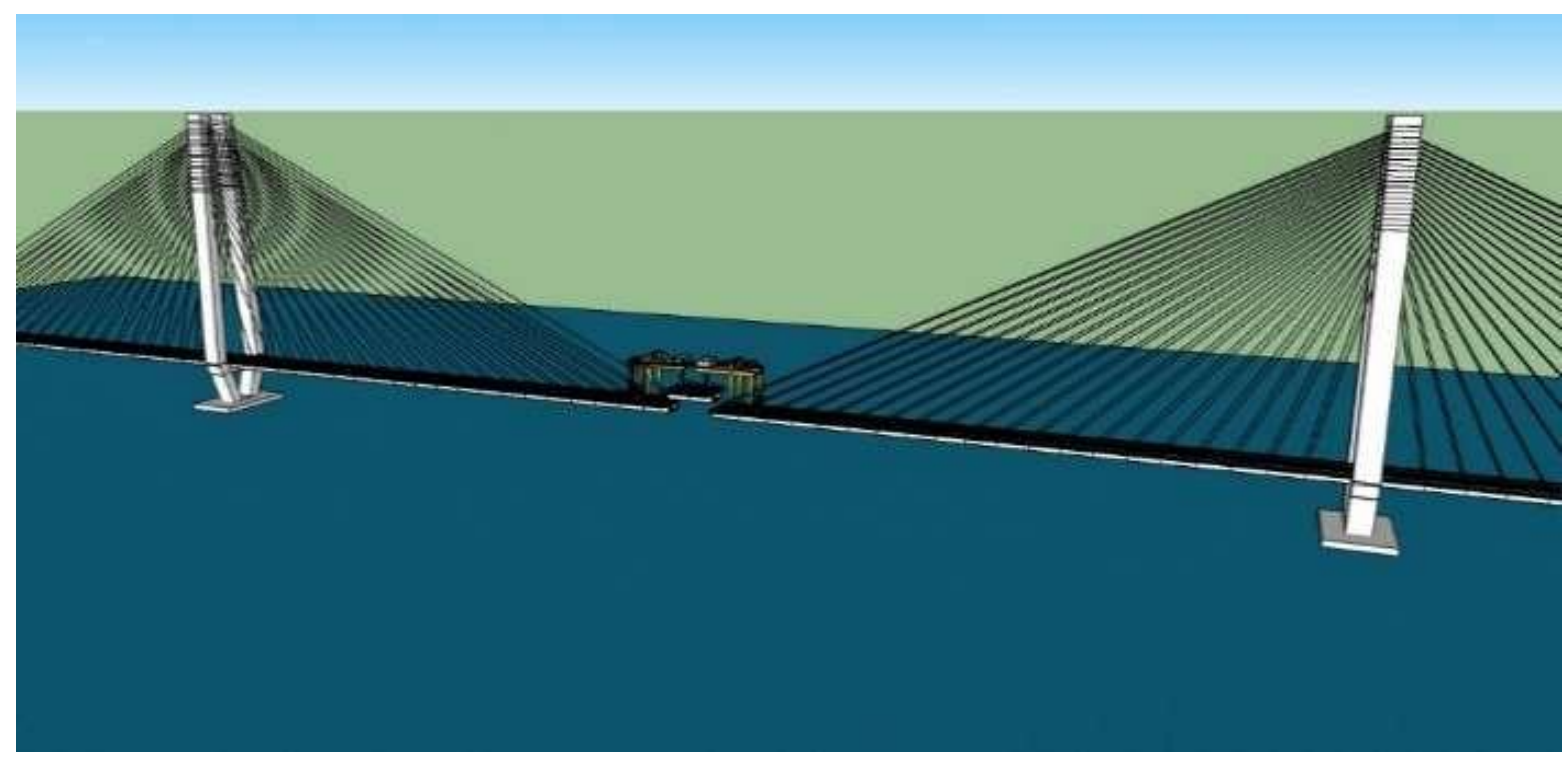

Gambar 4. Sketsa tahap konstruksi keempat

\subsection{Studi Literatur}

Berikut uraian beberapa studi literatur pada penelitian ini.

1. Konstruksi Jembatan Bentang Panjang Studi Kasus: Tatara Bridge disusun oleh Herbudiman, B. (2019), Dosen jurusan Teknik Sipil Fakultas Teknik Sipil dan Perencanaan Institut Teknologi Nasional Bandung.

2. Studi literatur yang ditulis oleh Saudara Purnawan, R. (2017), mahasiswa Jurusan Teknik Sipil Fakultas Teknik Sipil dan Perencanaan Institut Teknologi Sepuluh November dengan judul penelitian "Desain Jembatan Cable Stayed Sembayat Baru dengan Simple Plane System Menggunakan Metode Pelaksanaan Balanced Cantilever".

3. Studi literatur mengenai analisis tahapan konstruksi jembatan cable stayed berikutnya ditulis oleh Julinanda, Y. (2016), mahasiswa Jurusan Teknik Sipil dan Lingkungan Institut Pertanian Bogor dengan judul penelitian "Analisis Perilaku Struktur Jembatan Cable Stayed Dr. Ir. Soekarno di Manado Pada Tahap Konstruksi".

4. Selain literatur tentang analisis tahapan konstruksi jembatan cable stayed, terdapat juga perencanaan jembatan cable stayed yang ditulis oleh Saudara Jannah, M. (2019), mahasiswa Jurusan Teknik Sipil Fakultas Teknik Sipil dan Perencanaan Institut Teknologi Nasional Bandung dengan judul penelitian "Komparasi Perancangan Struktur Jembatan Cable Stayed Sistem Satu Bidang Dengan Dua Bidang".

\section{METODE PENELITIAN}

\subsection{Bagan Alir}

Tahapan-tahapan analisis pada penelitian ini dapat dilihat pada Gambar $\mathbf{5}$ yang merupakan bagan alir. 


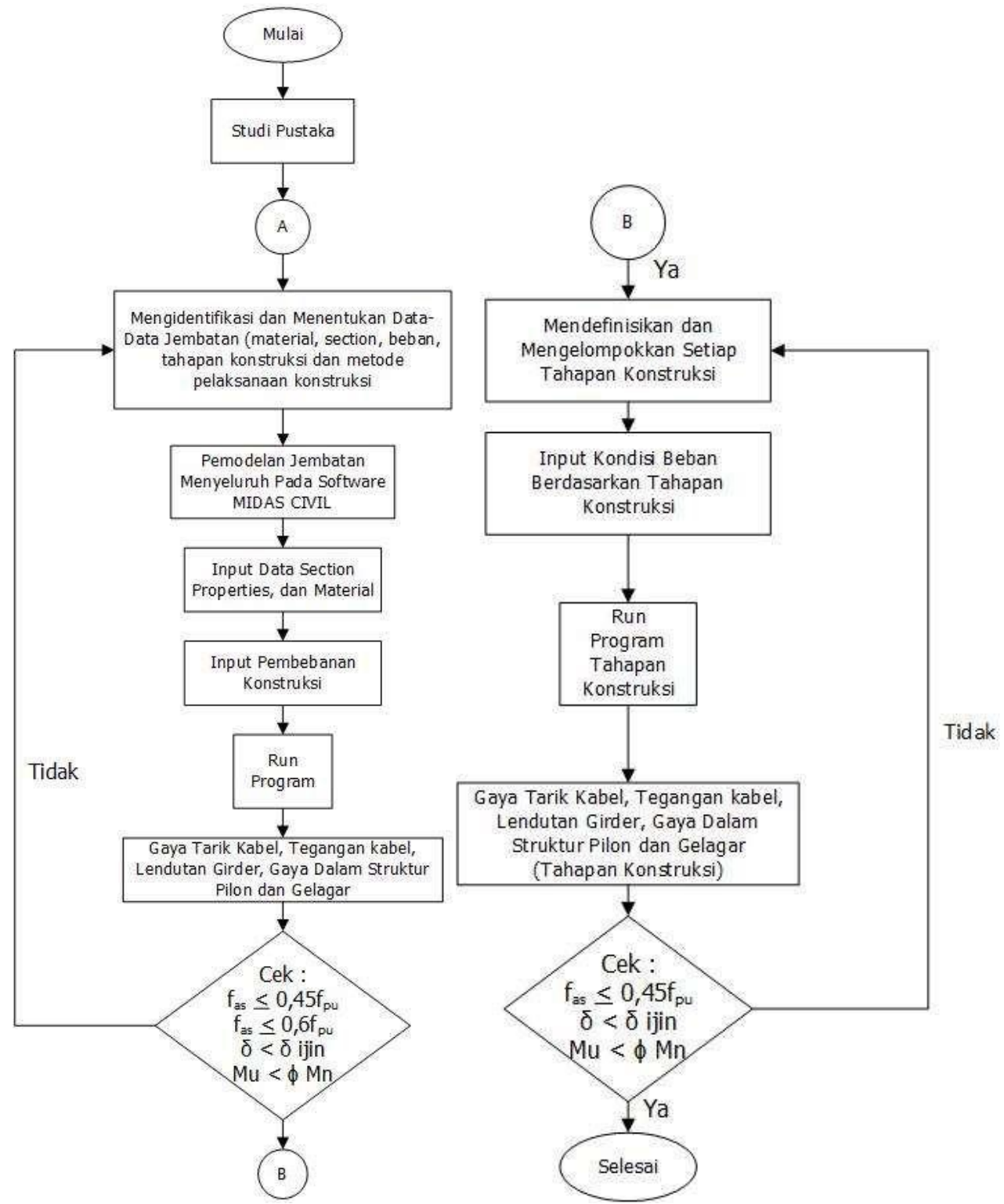

Gambar 3. Tahapan penelitian

\subsection{Batas Tegangan Kabel}

Batas untuk kondisi layan ditulis dalam sebuah rumus seperti pada Persamaan 1.

$$
f_{a s} \leq 0,45 f_{p u}
$$

Sedangkan batas untuk kondisi ultimit ditulis dalam sebuah rumus seperti pada Persamaan 2.

$$
f_{a s} \leq 0,6 f_{p u}
$$

halmana:

$f_{a s}=$ tegangan kabel yang terjadi $\left[\mathrm{N} / \mathrm{mm}^{2}\right]$,

$f_{a s}=$ tegangan ultimit kabel $=1.860 \mathrm{MPa}$.

Batasan tegangan awal kabel pada tahap pelaksanaan konstruksi jembatan direncanakan $20 \%$ $-30 \%$ tegangan putus agar mampu menahan beban pelaksanaan dan pelayanan. 


\subsection{Batas Lendutan Gelagar}

Lendutan izin jembatan cable stayed dengan gelagar menggunakan material beton ditulis dalam sebuah rumus seperti pada Persamaan 3.

$$
\delta \leq \frac{L}{800}
$$

halmana:

$L=$ lendutan yang terjadi $[\mathrm{mm}]$,

$\delta=$ Panjang bentang utama jembatan $[\mathrm{mm}]$.

\subsection{Batas Momen}

Batas kapasitas momen pada penelitian ini ditulis dalam sebuah rumus seperti pada Persamaan 4.

$$
M_{u} \leq \phi M_{n}
$$

halmana:

$M_{u}=$ momen ultimit $[\mathrm{kNm}] ;$

$\phi=$ faktor reduksi momen lentur $=0,8$;

$M_{n}=$ momen lentur $[\mathrm{kNm}]$.

\section{PEMODELAN DAN ANALISIS STRUKTUR}

\subsection{Pemodelan Struktur Jembatan}

Pemodelan struktur jembatan cable stayed dilakukan menggunakan software MIDAS Civil 2019 dengan fitur construction stage. Hal ini dilakukan untuk menghasilkan nilai-nilai gaya dalam, deformasi pada tahap pelaksanaan.

Pemodelan konstruksi jembatan bertahap dimulai dari konstruksi pilon yang dianggap sudah cukup kaku dilanjutkan dengan pemasangan gelagar pada segmen 1 sampai dengan segmen ke-21. Pemodelan jembatan tahap pelaksanaan dapat dilihat pada Gambar 6.

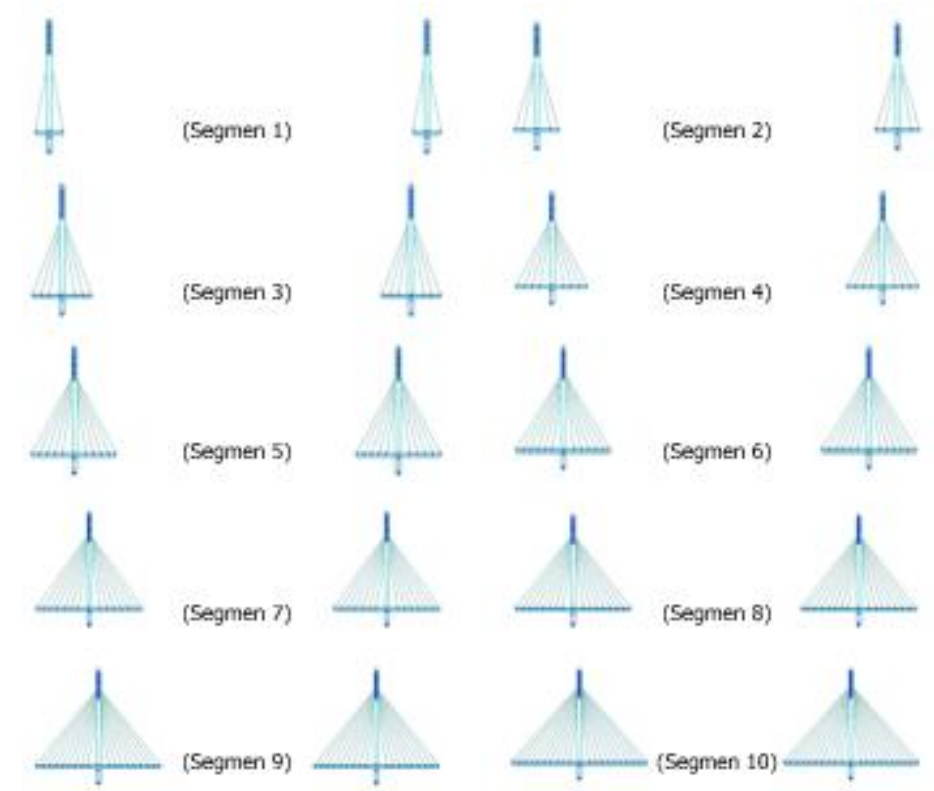

Gambar 6. Pemodelan tahapan konstruksi jembatan 

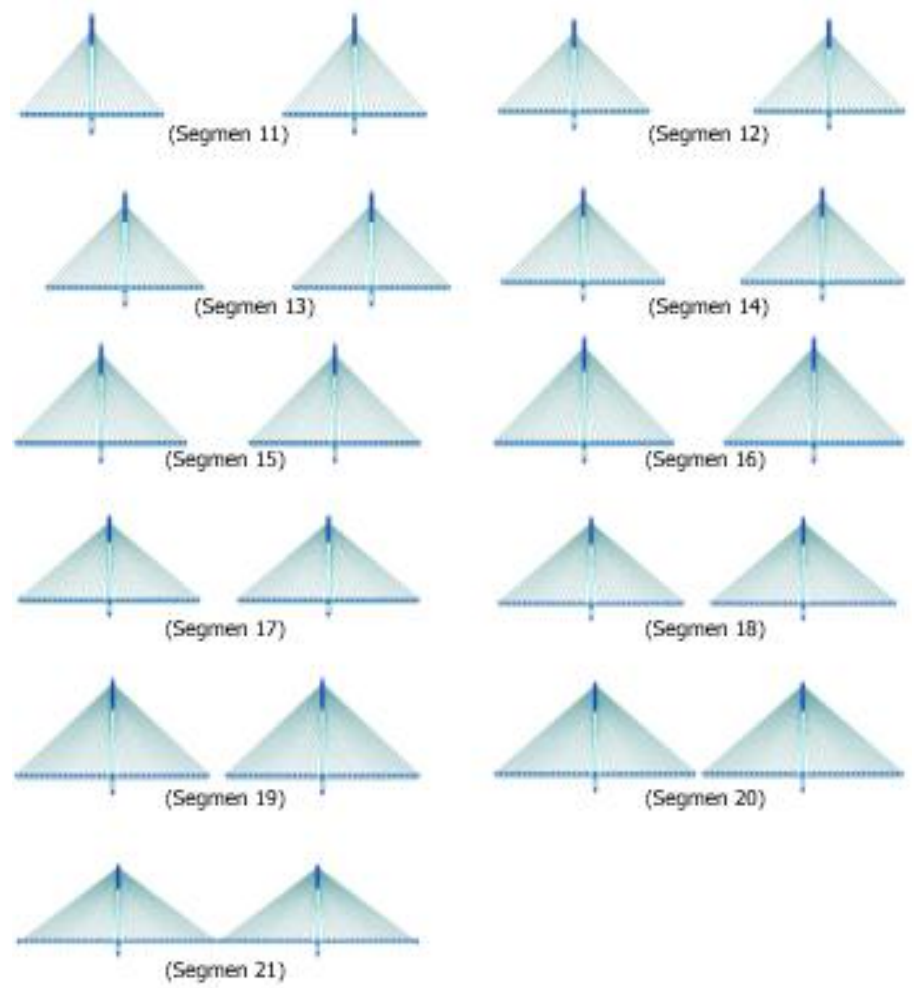

Gambar 6. Pemodelan tahapan konstruksi jembatan lanjutan

\subsection{Analisis Tahapan Konstruksi Jembatan Cable Stayed}

Analisa tahapan konstruksi jembatan pada penelitian dibantu menggunakan program MIDAS Civil 2019 yang dimulai dari pemasangan gelagar pada segmen 1 sampai dengan segmen ke 21. Hasil dari pemodelan tahapan konstruksi jembatan yaitu lendutan yang terjadi pada gelagar, tegangan yang terjadi pada kabel, dan nilai gaya-gaya dalam maksimum pada setiap tahapan konstruksi.

\section{PEMBAHASAN}

\subsection{Pengecekan Tegangan Kabel}

Kabel merupakan elemen jembatan yang berfungsi menyalurkan beban dari girder menuju pilon kemudian diteruskan ke pondasi. Tegangan kabel yang ditinau adalah nilai tegangan maksimum pada setiap tahapan konstruksi. Tegangan kabel diperoleh dari gaya aksial tarik maksimum yang terjadi setiap luasan kabel. Berdasarkan data yang dihasilkan, pada tahap pertama elemen kabel nomor 226 didapatkan nilai tegangan mengalami peningkatan pada tahap ke-8 yaitu $124 \mathrm{~N} / \mathrm{mm}^{2}$. Hal ini dikarenakan semakin panjang tahapan konstruksi, maka gaya aksial yang terjadi mengalami erection terakhir. Akan tetapi, gaya aksial yang terjadi masih berada di bawah 0,45 tegangan ultimit yaitu $837 \mathrm{~N} / \mathrm{mm}^{2}$, sehingga tegangan kabel yang dihasilkan aman pada tahap pelaksanaan. Tegangan kabel izin untuk kapasitas ultimit, tegangan kabel juga berada di bawah 0,6 tegangan ultimit yaitu $1.116 \mathrm{~N} / \mathrm{mm}^{2}$, sehingga aman untuk pasca konstruksi. Nilai tegangan kabel tertinggi pada main span left nomor 242, 242, 244 yaitu pada segmen 21.

\subsection{Pengecekan Lendutan Gelagar}

Lendutan merupakan penurunan yang terjadi akibat adanya pembebanan arah vertikal maupun horisontal. Lendutan yang terjadi harus di bawah dari syarat yang sudah ditentukan, sehingga struktur jembatan dapat disimpulkan aman. Lendutan dipengaruhi oleh kekakuan 
struktur jembatan. Semakin besar kekakuan struktur, maka lendutan yang terjadi akan semakin kecil. Perbandingan lendutan yang dihasilkan dapat disajikan pada Gambar 7.

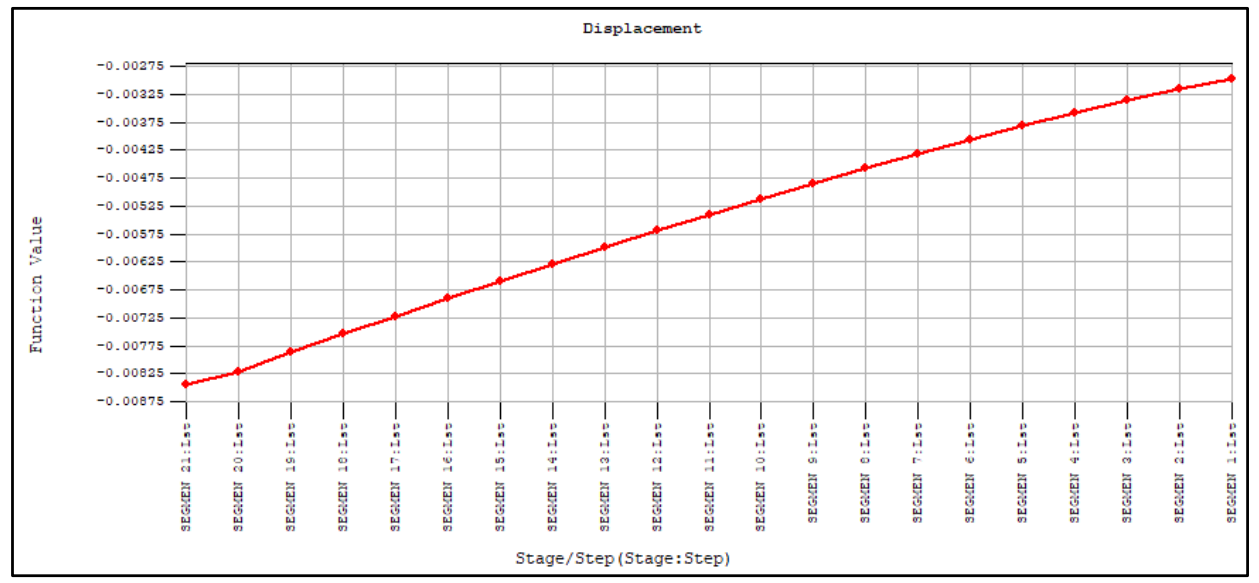

Gambar 7. Grafik lendutan maksimum gelagar pada tahap pelaksanaan

Nilai lendutan terendah terdapat pada segmen 1 yaitu 0,001 m. Segmen 1 merupakan tahap pelaksanaan pemasangan gelagar pertama. Nilai lendutan tertinggi terdapat pada segmen 20 yaitu $0,167 \mathrm{~m}$ yang terjadi pada side span struktur jembatan. Kemudian mengalami penurunan pada tahap 21 sebesar 0,153 m, dikarenakan posisi ini mengalami kesetimbangan kantilever dengan bentang panjang dan massa struktur terbesar. Akan tetapi, lendutan yang terjadi pada main span mengalami peningkatan yaitu 0,32 m. Sedangkan nilai maksimum lendutan kondisi layan yaitu $0,00146 \mathrm{~m}$.

Perhitungan lendutan izin menggunakan $L / 800$ dengan panjang bentang diambil terbesar yaitu $300 \mathrm{~m}$, sehingga didapatkan hasil perhitungan adalah 0,375. Dalam penelitian ini, nilai lendutan yang terjadi pasca konstruksi dan tahap konstruksi jembatan berada di bawah batas izin yaitu 0,375 m, sehingga dapat disimpulkan bahwa struktur aman pada saat pasca konstruksi dan tahap konstruksi.

\subsection{Pengecekan Momen Ultimit Gelagar}

Jenis gelagar yang digunakan adalah gelagar box prategang. Dalam pelaksanaannya gelagar box diberikan tegangan terlebih dahulu. Sehingga Ketika proses penarikan bagian serat atas akan mengalami gaya tekan, sedangkan bagian serat bawah mengalami gaya tarik. Tendon menimbulkan gaya tarik dan beton dapat menahan gaya tekan. Momen pada girder disebabkan oleh gaya lentur yang terjadi akibat adanya beban tegak lurus pada gelagar dan menjadikan gelagar melentur. Momen yang dihasilkan merupakan momen negatif. Momen terbesar terjadi pada segmen 21 yaitu 18.286,31 kNm; sedangkan yang terendah pada segmen 11 yaitu 20,43 kNm.

Perhitungan momen nominal merupakan perkalian faktor reduksi sebesar 0,8 dengan momen nominal, sehingga didapatkan hasil perhitungan yaitu 190.500,13 kNm. Momen yang terjadi akibat pembebanan memiliki nilai di bawah kapasitas izin, sehingga dapat disimpulkan struktur aman pada tahap pelaksanaan dan juga pasca konstruksi.

\section{KESIMPULAN DAN SARAN}

\subsection{Kesimpulan}

Berdasarkan hasil dari tahapan konstruksi jembatan cable stayed pada penelitian ini dapat disajikan sebagai berikut: 
1. Beban mati pada jembatan pasca konstruksi meliputi beban sendiri struktur, dan beban mati tambahan. Sedangkan beban hidup pada jembatan pasca konstruksi meliputi beban lajur, beban truk, gaya rem, beban pejalan kaki, dan beban angin.

2. Pemodelan tahapan pelaksanaan dan analisa struktur dibantu dengan Program MIDAS Civil 2019 menggunakan fitur construge stage untuk menghasilkan respon gaya-gaya yang bekerja pada setiap tahapan konstruksi.

3. Tegangan kabel maksimum yang dihasilkan pada pemodelan jembatan pasca konstruksi sebesar 406,4 MPa dengan batasan tegangan putus sebesar $837 \mathrm{MPa}$; sehingga struktur jembatan aman pada pasca konstruksi. Sedangkan untuk tahap konstruksi; tegangan maksimum diperoleh dengan nilai 224,7 MPa; sehingga struktur jembatan juga aman pada tahap konstruksi.

4. Lendutan box girder yang terjadi pada pemodelan jembatan pasca konstruksi sebesar $0,00146 \mathrm{~m}$ dengan batas lendutan $0,375 \mathrm{~m}$.

5. Untuk pelaksanaan pemasangan box girder jembatan digunakan metode kesetimbangan kantilever dengan alat bantu float crane dan travelling crane/lifting frame.

6. Nilai lendutan terendah terdapat pada segmen 1 yaitu $0,001 \mathrm{~m}$. Nilai lendutan tertinggi terdapat pada segmen 20 yaitu 0,167 m yang terjadi pada side span struktur jembatan. Kemudian mengalami penurunan pada tahap 21 sebesar $0,153 \mathrm{~m}$. Lendutan yang terjadi memiliki nilai dibawah lendutan izin, sehingga dapat disimpulkan struktur aman pada tahap pelaksanaan dan juga pasca konstruksi.

7. Momen terbesar terjadi pada segmen 21 yaitu $18.286,31 \mathrm{kNm}$; sedangkan yang terendah pada segmen 11 yaitu 20,43 kNm. Momen yang terjadi akibat pembebanan memiliki nilai dibawah kapasitas izin yaitu 190.500,13 kNm; sehingga dapat disimpulkan struktur aman pada tahap pelaksanaan dan juga pasca konstruksi.

\subsection{Saran}

Adapun saran-saran yang dapat dilakukan untuk penelitian selanjutanya sebagai berikut:

1. Dalam pembebanan tahapan konstruksi pada Program MIDAS Civil 2019, perlu dilakukan pemodelan beban travelling crane/lifting frame yang lebih mendetail sehingga distribusi beban lebih mendekati kondisi nyata.

2. Analisis dapat dilengkapi dengan construge stage pada elemen pilon mulai sehingga analisis lebih mendetail untuk keseluruhan tahapan konstruksi jembatan cable stayed.

\section{DAFTAR RUJUKAN}

Badan Standardisasi Nasional. (2016). SNI 1725:2016 tentang Pembebanan Untuk Jembatan. Jakarta: Badan Standardisasi Nasional.

Herbudiman, B. (2019). Konstruksi Jembatan Bentang Panjang Studi Kasus: Tatara Bridge. Bandung: Jurusan Teknik Sipil Institut Teknologi Nasional Bandung.

Jannah, M. (2019). Komparasi Perancangan Struktur Jembatan Cable Stayed Sistem Satu dengan Dua Bidang. Tugas Akhir. Bandung: Jurusan Teknik Sipil - Institut Teknologi Nasional Bandung.

Julinanda, Y. (2016). Analisis Perilaku Struktur Jembatan Cable Stayed Dr. Ir. Soekarno di Manado pada Tahap Konstruksi. Tugas Akhir. Bogor: Jurusan Teknik Sipil dan Lingkungan - Institut Pertanian Bogor.

Purnawan, R. (2017). Desain Jembatan Cable Stayed Sembayat Baru dengan Single Plane System Menggunakan Metode Pelaksanaan Balanced Cantilever. Tugas Akhir. Surabaya: Jurusan Teknik Sipil Infrastruktur - Institut Teknologi Sepuluh Nopember. 